\title{
Was it Worth it? Using Student Loans to Finance a College Degree
}

\author{
William L. Nuckols \\ Old Dominion University \\ Kim E. Bullington \\ Old Dominion University \\ Dennis E. Gregory \\ Old Dominion University
}

\begin{abstract}
This qualitative study explores the perceptions of value added to the lives of graduates who borrowed money to fund their college educations. Through the lens of cognitive dissonance theory, five themes emerged. Overall, the study participants agreed that the ability to take on student loans to fund their education was worth it, but on the other hand feel overburdened with the cost of paying back their loans. This paper also provides a foundation for future research and identifies public policy shortcomings and suggests solutions.
\end{abstract}

Keywords: student loans, financial aid, debt, degree satisfaction, qualitative research

Since the 1970s, a college degree has become more commonplace, more accessible, and more expensive (Carlson \& McChesney, 2015; Kuzma, Kuzma, \& Thiewes, 2010; Lobo \& Burke-Smalley, 2019). Student loan debt has been the subject of many discussions in fields like economics, higher education, employment, and politics (Cunningham \& Santiago, 2008; Popsescu, 2018; Scott-Clayton, 2018). The topic has culminated into prime-time subject matter with the 2020 Presidential election on the horizon and potential candidates offering proposals from no changes to the current system to full student loan debt forgiveness. Accumulated student debt can have a debilitating effect on those who have borrowed money to attend college (Akers \& 


\section{Higher Education Politics \& Economics}

Chingos, 2018; Miller \& Nikaj, 2018). In response to a decline in state funding, many colleges and universities have increased tuition and fees (Mitchell, Leachman, Masterson \& Waxman, 2018), and many of those interested in pursuing higher education have turned to student loans to help (initially) lessen the cost of postsecondary degree or certificate (Mueller \& Yanellis, 2019; Nuckols, 2016).

\section{Background of the Problem}

The numbers are staggering. Currently, there are 44 million student loan borrowers (Experian, 2018) with a combined debt of \$1.569 trillion and climbing (Board of Governors of the Federal Reserve System, 2019). In 2018, 53,749 unique borrowers submitted applications for Public Service Loan Forgiveness; of those 610 were approved (Federal Student Aid, 2019). This is compounded by the fact that 5.1 million borrowers are in default in excess of one hundred billion dollars. Federal student loan debt has grown $60 \%$ in the last ten years and is forecast to grow to $\$ 2$ trillion by 2021 (Byrne, 2018). With this rapidly increasing debt on individuals pursuing degrees, the question must be asked if it was worth it. Students who graduated in 2018 have an average student loan debt of $\$ 32,731$ (US Federal Reserve, 2017); average monthly student loan payments are $\$ 393$ (US Federal Reserve, 2017); and $11.5 \%$ of student loans are either in default or over 90 days late (Federal Reserve Bank of New York, 2018). It is vital that we understand the perceptions of student borrowers so that we can better prepare the next generation of students, inform policy, and keep the conversation on student borrowing moving forward. Our research question centers on the concept of student borrowers' perceptions of the value added from achieving a degree or certification. Accumulated student debt is becoming a larger and larger burden on student borrowers and the American people, so this study is an important contribution to help lift the veil on this situation.

\section{Purpose and Significance of the Study}

The purpose of this study is to explore the perceptions of value added to the lives of graduates who borrowed money to fund their college educations. A secondary purpose is to provide a foundation for future research and policy solutions related to access to education, economic stimulation of local and national economies, and lifting a veil off of the skilled labor fallacy, which we define as the belief that a college education is necessary over the need for skilled labor.

\section{LITERATURE REVIEW}

It is not well known that the advent of access to higher education is a product of the original G.I. Bill (Sibson, 2014). When the U. S. Government realized the popularity of the G.I. Bill, combined with demand for a more educated American population, the Cold War government enacted the Higher Education Act of 1965 (HEA) (20. U.S.C. ch. $28 \S 1001$ et seq.). The HEA created grant and scholarship programs, but also student loans. People then realized that college was more attainable and affordable (albeit through loans). However, it was not until the 1980s that the weight 
of student loans moved from taxpayers to individual borrowers (Fergus, 2018). As the federal government, during the Reagan administration, shifted its focus on higher education attainment being a private good, it has created an undue burden on individuals who are seeking education to satisfy job market needs and/or personal ambitions. This literature review covers four facets of student loan borrowers: shifts in the higher education market; financial literacy and the public perception of higher education; behavioral economics; and public policy for student loans and borrowing.

Since 1975, wage stagnation for middle- and lower-class Americans has been the rule. There has been no real wage growth since then. In fact, America is just moving back to the 1975 wage average (Sacerdote, 2017). The gross income of the average working American has been stagnant (DeSilver, 2018) while the costs of goods, services, and higher education have skyrocketed (Archibald \& Feldman, 2018).

A debate within higher education is whether it is a public or a private good, even though, as noted above, the federal government perceives it to be a private one. The American public views government spending on higher education as a fair, good, or excellent investment (93\%) (Drezner, Pizmony-Levy \& Pallas, 2018). The public funding of higher education is a public good, and the discussion of student debt pivots on higher education attainment being a private asset, thus the public good/private good conundrum. From the 1980s through the late 1990s higher education, then considered a growth industry - meaning having enrollment growth and governmental support for expansion (Levine, 2001) - became viewed as a mature industry - where students now get more loans than grants, higher education institutions are battling declining resource allocations, and shifts in faculty roles from mostly tenure-track to heavy reliance on adjunct/contingent faculty (Manning, 2018). When this phenomenon occurs, government funding begins to decrease as the public focus on the industry shrinks.

More recently, the Great Recession of 2008 had Americans facing unemployment, an unstable housing market, and created anxiety regarding financial security (Stoll, 2013). One in six Americans lost their jobs (Farber, 2011). Although enrollment in higher education grew from 18.2 million to 21 million between 20072010 (Snyder, 2012) and the Federal government attempted to mitigate the impact on higher education by increasing the Pell Grant and providing more generous student loans, colleges and universities were faced with dramatic budget shortfalls (Barr \& Turner, 2013). Student borrowing also increased significantly during this period, especially with unsubsidized Stafford loans (Wei, 2010). Private student loans also increased significantly (Barr \& Turner, 2013) and students defaulted on these at a rate of 1.5 times higher than with public loans (Moody's Investors Service, 2011).

With the reduction or stagnation in public funding, there is more governmental regulation and control and there are demands for accountability. This also means that as a mature industry, education must respond to satisfy the needs of society meeting demands on a global level (Levine, 2001). With such an overwhelming sentiment, there should be an alignment of the student loan debt discussion and the public expenditure position. The "concept" of higher education is a public good, however the degree attained is viewed as a private one (Hensley, Galilee-Belfer, \& Lee, 2013). With such disparity of viewpoints regarding public/private benefits, a re-alignment needs to occur. 


\section{Higher Education Politics \& Economics}

\section{Higher Education Market Shift}

With a change in the social value of a degree or graduate certificate shifting from a public good to a personal asset, the public funding model for higher education has constantly reduced each year (Alexander, 2011; Baez, 2013; Levine, 2001). Since the early 1970s, the college student has evolved from the traditional to the more nontraditional student (Iloh, 2018; Levine, 2001). Another shift in the higher education market occurred when the public institution funding model changed from enrollmentbased, to incentive- or performance-driven, with greater accountability toward measurable outcomes (Kelchen, 2018; Tandberg \& Hillman, 2014).

\section{Financial Literacy and the Public Perception of Higher Education}

First generation, low socioeconomic, and minority students can bring disparities in financial literacy to the higher education setting (Greenfield, 2015; Smith \& Barboza, 2014). Students often do not realize the true weight of their student loan burden until near or after graduation (Durband \& Britt, 2012), this is especially true for first generation and minority students (Blagg \& Blom, 2018). The attainment of a college degree or certificate can be viewed as a private benefit to a graduate, since the possible lifetime earnings potential is increased (Drezner et al., 2018). This psychological shift has created the mindset of blaming the victim (Mueller \& Yannelis, 2019) (e.g. cumulative debt incurred is not commensurate with expected earnings generates a heightened level of scrutiny of the borrower) rather than the other factors that have led to an increase in educational affordability (Mitchell et al., 2018). This macro approach has forced students to adjust their financial literacy and has placed a burden on financial aid offices that are now additionally tasked with educating student loan borrowers on debt accumulation (Johnson, 2016).

\section{Behavioral Economics}

Generally, behavioral economics examines the psychology behind conventional economics and personal decision-making processes, including financial decisionmaking (Camerer \& Loewenstein, 2004; Castleman, Baum, \& Schwartz, 2015; Smith \& Barboza, 2014). Loss aversion and debt/loan aversion affect students' willingness (or unwillingness) to finance educational costs through student loans (Nuckols, 2016). The student is now forced to decide on return-on-investment (ROI) and become more educated on the potential value or risk their degrees will bring them (Blagg \& Blom, 2018).

Financial aid programs and lending in general have historically been seen through a cost-benefit analysis lens. In a very general sense, if there is access to money, albeit through loans, college is affordable because the benefit of the college degree should outweigh the debt burden incurred (Baum \& Schwartz, 2015). However, due to limited information on student borrowing, borrowers do not understand the complexities of the loan processes, this is especially true with more vulnerable populations, such as first-generation and/or economically challenged college students 
(Baum \& Schwartz, 2015). These students may also face the challenge of debt aversion, where they are reluctant to borrow because of the possibility that they will not be able to pay back the money owed and thus they enter the labor market at lower qualifications to ensure a stable paycheck (Boatman, Evans \& Soliz, 2016). Conversely, the concept of overconfidence (e.g. high school was easy, so college should be too; I can afford to pay back loans once I get my degree, etc.) plays a part in decision-making and students who have a low chance of educational success may have debts that are not proportionate to their eventual earnings (Aronson, 2017; Baum \& Schwartz, 2015). If consumers do not understand the complexities of student loan borrowing, are too afraid to borrow, or have too much confidence in their ability to succeed as students, it will be difficult for them to find the worth of their college education compared to the debt incurred to pay for it, which is the basis of this research.

\section{THEORETICAL FRAMEWORK}

Cognitive dissonance occurs when a person experiences an unsettling stress point which interferes with a prior belief or value. In other words, cognitive dissonance refers to a point in time where there is conflict with previous perceptions. Cognitive Dissonance Theory (CDT) (Festinger, 1957), therefore, seeks to examine how people either justify their behavior or deal with the inconsistencies created through the cognitive dissonance experience (Cooper, 2007). The desire for harmony is a part of human nature, and we strive to mitigate instances of disharmony (or dissonance). However, when the dissonance becomes so evident, we must either accept or refuse to accept the change to eliminate the dissonance (Festinger, 1957).

\section{Three Cognitive Dissonancy Theory Categories}

CDT can be broken into three distinct categories: forced compliance behavior, decision-making, and effort. Forced compliance behavior develops when someone is publicly asked to do something outside of their comfort zone (i.e. doing something that goes against values and beliefs). Decision-making can create dissonance by forcing someone to make one decision over another (i.e. deciding between a job that pays more or working in a location that is more appealing). When spending a great deal of effort on something (i.e. pursuing a certificate or degree), people may create dissonance if there is a perception that their effort did not meet their expectations. This study focuses on the effort category of CDT as we are specifically examining the perceptions of value-added after completing a certificate or degree and having taken out student loans to accomplish this endeavor.

\section{Consumer Behavior and Cognitive Dissonance Theory}

Education is a facet of consumerism. Because we pay for our education, we are consumers. Examining CDT through a consumer behavior lens is important. Gbadamosi (2009) found that there are three main conditions that can create a feeling of cognitive dissonance as a consumer: a) the decision must be important to justify 


\section{Higher Education Politics \& Economics}

the money spent on the product; b) the psychological cost must also be weighed when justifying the cost of the product; and c) the product is relevant to the buyer.

So how does CDT fit within the scope of our study? Simply put, the respondents may experience some level of cognitive dissonance when they understand the full impact of the burden incurred in order to receive a diploma or certification. There are three ways to reduce dissonance: a) returning to harmony by minimizing the dissonance; b) researching and learning more about what is causing the dissonance; or c) changing their attitudes (Festinger, 1957; Mulikin, 2003). It should be noted, however, that although these steps are taken, they do not necessarily reduce the dissonance. A criticism of CDT is that it is difficult to objectively measure; however, we believe that through the voices of the participants, we will be able to create a vivid picture of their perceptions.

\section{METHOD}

Phenomenological research seeks to examine the lived experiences and phenomena encountered by the research participants' own descriptive analysis. Phenomenology allows participant voices to emerge (Privitera \& Ahlgrim-Delzell, 2019) through the phenomenon of accumulated student debt as a result of the completion of a degree or certificate from a public institution.

The following research question guided this qualitative study: What are borrowing students' perceptions of the value added to their lives by their earned education when considering accumulated student debt?

\section{Research Design}

For the purposes of this research study, quantitative responses from a questionnaire were analyzed in Nuckols' (2016) dissertation. That questionnaire also included an invitation for voluntary qualitative responses. This qualitative research design used open-ended written responses on a questionnaire from Nuckols' (2016) dissertation. This allowed participants to respond in their own voice about their perceptions on the value of their educational debt.

\section{Epoché}

Two of the researchers in this study have taken out significant amounts of student loans, so it must be acknowledged that there may be some inherent biases and preconceived notions about student perceptions of debt and borrowing. The researchers have also worked in higher education institutions for many years and have many varied experiences with their own - and with others' - concepts of borrowing. To try to eliminate these possible biases, the researchers attempted to suspend any preconceptions related to this study through bracketing.

\section{Trustworthiness}


To increase trustworthiness, the researchers used Noble and Smith's (2015) strategies to ensure study credibility. This includes accounting for personal biases, thorough record keeping, using the voices of participants verbatim, and attempting to reduce research bias (Noble \& Smith, 2015).

\section{Data Collection}

Graduates/completers of a public institution in the southeastern region of Virginia completed an online survey instrument. While commonplace today, online survey administration is not only convenient (especially where large populations are involved), but the results have been determined to be superior to those obtained through paper mail services (Kraut, Olson, Banaji, Bruckman, Cohen \& Couper, 2004). The online process was used here to allow for a reduced cost in survey administration, convenience in analysis once the results are obtained, and in an attempt to obtain greater participation.

The survey instrument was checked for criterion validity through a survey blueprint which ensured a relationship between the survey and research questions. Content validity was determined through an analysis of the survey questions by subject matter experts in a pilot study. The pilot participants included 37 peers from higher education with expertise in higher education attainability, representing six institutions, on two continents. Feedback from the subject matter experts was ensured for format and clarity of the instrument.

Nuckols emailed the survey introduction and instructions, along with the relevant link to the survey to the population on the same date in the Fall of 2014, beginning the data collection process. The researcher monitored the responses daily to ensure an effective collection process, fielding some procedural questions from participants. On Days 7, 14, and 21 a reminder email notice was sent to the population to encourage a continued participation. A final reminder notice, complete with the deadline was sent on Day 26. Nuckols closed the survey on Day 28.

The population for this study is graduates/completers who accumulated some level of debt in order to finance some or all costs associated with earning a degree or graduate certificate at a large doctoral granting public institution of higher education. The subject institution is physically located in the Mid-Atlantic region of the United States in southeastern Virginia.

The sample for this study was derived from the graduates and completers of a degree or graduate certificate program from the subject institution. The institution's alumni affairs office provided a list of the most recent email addresses for all completers from December 2008 through August 2014, the subject years of the study. The total email addresses in the provided population was $n=22,496$ (Nuckols, 2016).

A total of 1,075 responded to the survey (4.8\%). Of the 1,075 responses, 191 started but did not complete the survey, requiring their removal from the viable respondents. The remaining 884 contained 100 who did not complete the dependent variable questions, so they were eliminated from analysis, leaving 784 valid cases and a response rate of $3.5 \%$. While this response rate is considered low, it does not indicate nonresponse error (Dillman, Smyth, \& Christian, 2014). 


\section{Higher Education Politics \& Economics}

The responses to Survey Question 6, "How long has it been since the completion of you most recent degree or certificate?" showed 6\% completed in 0-6 months prior to the survey; $9 \%$ completed $7-12$ months prior; $14 \%$ completed $13-18$ months prior; $11 \%$ completed $19-24$ months prior; and $60 \%$ completed more than 24 months prior to the survey's administration. The sample reported a split of $35 \%$ male, $65 \%$ female. Other relevant demographic data show the sample reported $68 \%$ as "Caucasian/White," 20\% "African American," 4\% "Asian/Pacific Islander," 3\% "Latino/ Hispanic," 1\% "Native American/Alaskan," and the remaining respondents reported as "Other," or preferred not to disclose their ethnicity. Marital status was nearly evenly split between married (46\%) and single (45\%), with an additional 5\% who were divorced, $3 \%$ who reported being in a domestic partnership, and $1 \%$ widowed. The dominant age range of the sample was $23-27$ years old (40\%). The remaining age breakdown was as follows: $35 \%$ were age $28-35,14 \%$ age $36-45,10 \%$ 46 and over, and $1 \%$ reported in the $18-22$ age range. Of those who completed the quantitative survey instrument, 102 chose to voluntarily offer qualitative details about their debt accrual (Nuckols, 2016). It is from these responses that this study derives.

\section{Data Analysis}

First and second order coding was used to find emergent themes. For first order coding, the researchers examined the qualitative responses from Nuckols' (2016) survey on students' debt perception. Concept coding was used to lump data into meaningful themes. For second order coding, the researchers further condensed the first order themes into meaningful units (Miles, Huberman \& Saldaña, 2020).

\section{RESULTS}

There were 102 qualitative responses to Nuckols' (2016) survey. Several themes emerged from the data analysis regarding consumers' perceptions of value added. These themes represent the voices and perceptions of student borrowers. First order coding resulted in thirteen separate themes, which were then condensed into five: Impact of Debt, Defaulters, Aversion and Awareness, Increased Financial Literacy, and Was it Worth it? during second-order coding.

\section{Theme One - Impact of Debt}

Many respondents identified the impact that their student loan debts had on them. The findings show that borrowers felt they were not adequately prepared for the amount of debt incurred.

Borrowers felt overwhelmed by the amount of debt or the size of their payments. Respondents indicated that they were not aware how high their monthly payments would actually be. One even said "It is ridiculous! I owe money [...] that I will never be able to repay. No one should have to go through spending this type of money [...] for an education." Another said that she felt that her debt was "debilitating" and that both her and her husband felt "stuck financially"; she ended her comment by adding, "[we] are unable to consistently pay our loans. If we do, then we are usually not 
paying some other bill that is due." Finally, another respondent said that paying close to $\$ 1,000$ per month was "disgusting and discouraging."

Borrowers were also very introspective about their loans. One respondent said "proceed with caution before taking out a loan. [T] he most important thing is to go in with a plan for your higher education. [D]on't assume the debt will always pay off." Another quipped,

[p]eople should stop crying about college cost, yes it is expensive, and yes it could be less expensive ( I guess ), but no one has to go to college [...] just pay your dues, study hard, and over all [sic], choose a field that will [guarantee] a job, or even better ' a good paid job.'

Some even provided advice for future borrowers. They caution against going to outof-state colleges and universities and to use community college for the first two years. "Racking up a lot of student loans does not have a good return on investment."

\section{Theme Two - Defaulters}

When people face massive debts, there is a chance of defaulting on that loan. We found that many respondents were in default for various reasons including necessary living expenses. One respondent said that the monthly payment was "just too much in conjunction with other bills." Another remarked that healthcare payments jumped to " $\$ 620$ per month" for the family and because of the need to pay those medical bills, the student loan payments became less of a priority. Some respondents also indicated they were switching careers, unemployed, or not fully employed. One respondent indicated that it was necessary to work part-time because it was difficult to find a fulltime job in that career field. Because of working part-time, some respondents said they were not able to pay their loans. A respondent very sardonically remarked about "smashed" credit after being a "little" late on a student loan payment. Another said, "I did not have enough money each month to live and cover necessary expenses."

\section{Theme Three - Aversion and Awareness}

Taking on large amounts of debt and facing the repayment of it brought about many feelings of aversion. Because borrowers tended to resent their debt burden, they reported being more averse to the thought of taking on more debt or being introspective about their college experience.

\section{Aversion}

Respondents, on more than one occasion, echoed that not everyone deserves to (or should) go to college. Thinking back, many reflected on their aversion to continue their education if more loans were involved. "I would have to know that I would be able to make enough money to pay it back without having to be locked into a long term [sic] burden. One respondent discussed the perceived money that for-profit institutions are making while their students are shouldering the debt. 


\section{Higher Education Politics \& Economics}

\section{Awareness}

"I always say that my degree is the most expensive piece of paper I have." This quote probably rings true to many people. Respondents were very introspective about the amount of money borrowed as well as the amount of money they have to repay. Many responded that they would not go back to higher education if there was the possibility of incurring more student loan debt; in fact, most responded that the only way they would continue their education was if it were funded through grants, scholarships, or through their employers. One respondent placed the debt burden on the lenders. "Sallie Mae and other private loan institutions make it so you spend the rest of your life in debt." Another blamed difficulty repaying loans on the "crumbling job market" while comparing our education system to the more "obtainable" systems in Germany and Australia. However, some understood that the burden was largely based on their ignorance when taking out student loans. "This ignorance is primarily a result of an overly-forgiving society that allows for easy [c]redit with limitations on what lenders can do to force repayment." Many also echoed the sentiment of "if only I knew then what I know now."

\section{Theme Four - Increased Financial Literacy}

Although there is required entrance student loan training prior to accepting a student loan and further exit loan counseling at graduation or at the end of student loan eligibility, many respondents indicated that they were not prepared for the actual payments or managing their finances.

In the beginning of their student loan journey, some were not prepared for the cost of college. "I had no idea what I was getting myself into at the age of 18 signing all those forms for financial aid." Respondents added that more financial literacy needs to be available during the college decision process and at college orientations.

Many also discussed the need for individual or additional counseling so there is a more thorough understanding of the true impact of the debt that borrowers are incurring. One said that students should be counseled in person each time they add to their student loan burden to ensure they truly understand what their payments will look like when interest is added. Respondents indicated that people borrow without knowing or understanding how these repayments will affect their credit and their lives in the long run. One student quipped "[t]he system is very unfair and backwards to students." There were also calls for the elimination of accrued interest by respondents among desired solutions, although there were even more statements on completely avoiding student loan borrowing altogether.

\section{Theme Five - Was it Worth it?}

Overwhelmingly, respondents indicated that the debt incurred was more negative than positive to them. Two subthemes emerged: negative value and positive value.

\section{Subtheme: Negative Value}


Many respondents did not believe that borrowing money to pay for college was worth it. Some equated their education to luxuries and the jobs they currently have are not equivalent to their level of education. One even remarked that the education received was worthless, especially when compared to the salary a non-college graduate peer was receiving. Another agreed by saying that an apprenticeship yielded more money than an entry-level job in the borrower's degree field. Many acknowledged that their higher education experiences were not worth the cost, postgraduation. There was also sentiment that there was no immediate benefit to their degrees, which may change in the future as they advance through the ranks.

\section{Subtheme: Positive Value}

While many responses skewed toward the negative, there were still some feelings of positive value regarding student loan debt. Many responded that without student loans, they would not have been able to achieve their degrees, both undergraduate and graduate. They also indicated that their degrees had value, not only in career attainment, but also in their compensation. One respondent said,

I have [sic] a number of friends who use a lack of funding as an excuse not to obtain a necessary education. If I were in their shoes, I would borrow whatever it took to complete my degree as soon as possible to start earning a higher wage.

Finally, respondents also agreed that while they do not like being in debt, it was worth it in the end. Some reasons were because they needed the degree to get the job they wanted, but also because of the "intellect and sophistication" gained while in college.

\section{DISCUSSION}

When there are competing debts, student loan debt is not always at the top of the priority list, especially when considering living expenses. When borrowers cannot afford to pay back their student loans, they can quickly go into default or at the very least be behind in payments. Overall, while perceptions about the value of a college education can vary, the results of this study agree with others that degree attainment, overall, is still worth it in a broad sense (Lobo \& Burke-Smalley, 2018; Nuckols, 2016; Sawhill, 2018) while the manner of investment in it requires further examination.

\section{Study Limitations}

This study had 1,075 respondents, however only 102 provided open responses. This study was also limited to alumni of a public institution who graduated between December 2008 and August 2014. The online survey, which was only open 28 days, was the only instrument used and the researchers did not reach beyond the results of the instrument. Those who have had a negative experience may also have been more ready to respond qualitatively. While the responses were limited, there was enough evidence for us to be confident the voices were representative of the population that was surveyed. However, it is important that this survey be replicated or a similar one 


\section{Higher Education Politics \& Economics}

be put in place for reproducibility of the findings. Survey bias could have been a factor. An attempt was made to not ask leading questions, but the simple nature of the study could possibly have created strong feelings toward borrowing for education.

\section{Implications for Theory}

Understanding consumer attitudes and behaviors through Cognitive Dissonance Theory can help theorists navigate the underpinnings of student debt accrual. Finding the correct balance to determine theoretically whether taking on significant amounts of debt is important at the national, state, and local levels. These findings point to the tremendous importance of the dissonance encountered during and after the decision to borrow money to attend school, and the dissonance may never disappear (Oliver, 1997). Further, there is a need to understand how borrowers cope with the debt incurred. Examination of student borrowing through the lens of Cognitive Dissonance Theory can increase the understanding and financial literacy of funding education through student loans. If there is no perception of value added from the effort category of CDT (i.e. cost) of attaining the degree or certificate, the reward has not exceeded the risk and the consumer is not satisfied with the end result. Alternatively, the effort may have been worth it, but the perception of the value of the debt may still be negative.

\section{Implications for Practice}

The results of this study can inform practitioners on many levels. The first is student affairs practitioners. By understanding the satisfaction level of student loan borrowers, higher education administrators can focus on better preparing students who are considering taking on student loan debt through programs that go deeper into the concepts of borrowing and repayment. The second is the Federal government. Expanding the educational programming for students (and parents) who are applying for Federal loans is necessary. Moreover, the existing exit loan counseling through the Federal government should better prepare students as they go into repayment. Private student lenders are another category that should provide better educational programming prior to releasing student loan money. The concept of caveat emptor can no longer apply to student loan borrowers when student loan debt is increasing at such a rapid pace. For policymakers on many levels, the benefits of low-cost community colleges are fueling the free college movement (e.g. publicly funding community colleges to certain populations, etc.). In addition, the policy decision to eliminate college load debt being put forward by 2020 presidential candidates will ensure broader discussions of college costs and even if never enacted may refocus the discussion for years to come.

Student loan debt and the issue of repayment and default has a lasting impact on the economy overall. As the educated populace has fewer resources upon entering the repayment phase of their loan cycle, each dollar spent on interest repayment yields one less dollar for local food and entertainment businesses (restaurants, taverns, theaters, etc.), less for retail stores, and less for major purchases (home, car, etc.) (Akers \& Chingos, 2018). By exploring new policies, enhancing existing policies 
available to debtors, and other ideas such as student loan reduction or cancellation will help the economy in the long run. In fact, there are increasing calls for significantly reducing or eliminating student debt at the federal level. Economists at the Levy Institute ran a simulation that modeled debt cancellation which showed promise in increasing the GDP, decreasing unemployment, as well as having little effect on inflation and interest rates (Fulwiler, Kelton, Ruetschlin, \& Steinbaum, 2018).

\section{Future Directions}

This study is a springboard into a full research agenda. With the current focus on student loan borrowing and repayment and the increasing regulations associated with them, there are many avenues for future research. First is the development of a thorough understanding of consumers through several lenses, including behavioral economics, decision analysis, and risk and benefit analyses. Knowing how consumers justify the incurred debt is critical. It is worth asking whether potential borrowers understand the true cost of their education. This can be examined through multiple approaches such as generational theory, consumer behavior, and an analysis of the job market.

\section{Debt Aversion}

A deeper examination of the perceptions of value-added regardless of the amount of debt is still important. There are borrowers who have manageable levels of debt and there are borrowers who have debt they believe they will never be able to repay. Understanding debt aversion and how borrowers navigate the decision process is vital. The impact that student debt has on college graduates can be overwhelming. While it is always easier to look in the rear-view mirror, it is important that borrowers truly understand the reality of student loan payments as well as the job market they are entering.

It would be worthwhile to continue a study like this through examining specific populations. With the increase of non-traditional students, including veterans, who are becoming the new majority on college campuses, understanding the borrowing needs of these students is important. First generation students who do not necessarily have the same support network are also a critical population for examination. Community college students who do not complete or matriculate to four-year institutions are another group worthy of further study.

The title of this paper is "Was It Worth It?" This question can also be applied to the skilled labor fallacy. Many of us grew up with the thought that we would not be successful without a college degree. A comparison of college-educated workers and skilled trade laborers' salaries is also necessary. This harkens to the movie, Caddyshack (1980), where Danny Noonan tells Judge Smails, "I planned to go to law school after I graduated, but it looks like my folks won't have enough money to put me through college." The judge replies "Well, the world needs ditch diggers, too." It is time for U.S. citizens to remove the veil of shame from the trades as is the case in Europe and elsewhere. A college degree no longer guarantees success in the job 


\section{Higher Education Politics \& Economics}

market. With the popularity of stackable credentials, college degrees that aim to produce well-rounded contributors to society may not continue to be the path that some choose.

\section{Policy}

As of this writing, the Department of Education is re-examining the gainful employment disclosure requirement, which requires higher education institutions to disclose vocational employment rates and realistic income expectations of their graduates (Dembecki, 2019). However, it is likely that this level of accountability will remain in place either reworked in the impending HEA or via the College Scorecard. Policymakers should consider enhancing or increasing needs-based funding for higher education, including increasing the Pell Grant to realign its original intent with today's college cost, providing more repayment options such as incomebased and student loan forgiveness programs, and returning consumer protection measures under the U.S. bankruptcy code to the student lending arena. Another discussion is for those students who did not complete their degrees; this population is the most at-risk for default (Miller \& Nikaj, 2018) so finding avenues toward degree completion could be beneficial. Debt-strapped professionals are also an unintended consequence of student loan borrowing. Many do not have the ability to live at the level of their education and cannot contribute to the economy outside of the repayment of their loans (Robb, 2017). With few consumer protections, overall pattern of rising costs, easily accessible student loans, and a public perception that a degree is a personal good, better policies on student debt are warranted.

\section{CONCLUSION}

The question of "Was it Worth It?" has given some answers and generated more questions. Overall, the perception of value-added from this study has shown to be negative, however the value of education is overwhelmingly positive, personally and publicly. With such an optimistic outlook towards higher education attainment, the prevailing negative appears to be the cost and the financing of the degree or certificate. Unless there is a major change in political thought, the student loan debt problem is not going away. If measures are not taken to realign the overall value of education and the costs of educational attainment, the burden of higher education costs will continue to stagnate a generation, and this has the potential to stall the U.S. economy.

We asked if graduates/completers believed their debt burden was "worth it" for the results of the education they received. While we had mixed responses, and responses that went from one extreme to another, many of these students would not have their degree or credential if it was not for student loans. What remains to be asked is whether the total cost, with interest over the time of the loan, is worth the debt burden incurred for the degree. Cognitive Dissonance Theory indicates that the participant will attempt to harmonize to the extent possible the reason for the dissonance (Festinger, 1957) and we did see this in some of the responses where participants considered the value of their degree compared to the burden of their debt. 
We showcased a need for financial literacy and saw how some participants navigated some of their decision-making through behavioral economics lenses. While this study could not answer this completely, it still provides some answers to the question of the worth of a degree at the cost of borrowing (sometimes significant amounts of money) to finance an education.

\section{REFERENCES}

Akers, B., \& Chingos, M. M. (2018). Game of loans: The rhetoric and reality of student debt. Princeton, NJ: Princeton University Press.

Alexander, F. K. (Spring, 2011). Maintenance of state effort for higher education: Barriers to equal education opportunity in addressing the rising costs of a college education. Journal of Education Finance, 36(4), 442-450.

Archibald, R. B., \& Feldman, D. H. (2018). Drivers of the rising price of a college education. Minneapolis, MN: Midwestern Higher Education Compact.

Aronson, P. (2017). Contradictions in the American dream: High educational aspirations and perceptions of deteriorating institutional support. International Journal of Pscyhology, 52(1), 49-57.

Baez, B. (2013). An economy of higher education. In J. L. Devitis (Ed.) Contemporary colleges and universities: A reader (pp. 307-321). New York: Peter Lang.

Barr, A., \& Turner, S. (2013). Expanding enrollments and contracting state budgets: The effect of the Great Recession on higher education. The ANNALS of the American Academy of Political and Social Science, 650(1), 168-193.

Baum, S., \& Schwartz, S. (2014). Student aid, student behavior, and educational attainment. In B. L. Castleman, S. Schwartz, \& S. Baum (Eds.) Decision making for student success: Behavioral insights to improve college access and persistence (38-62). New York: Routledge.

Blagg, K., \& Blom, E. (2018). Evaluating the return on investment in higher education: An assessment of individual-and state-level returns. Washington, DC: The Urban Institute.

Board of Governors of the Federal Reserve System (2019). Consumer credit G.19. Retrieved from https:/www.federalreserve.gov/releases/g19/current/.

Boatman, A., Evans, B., \& Soliz, A. (2016). Understanding student loan aversion in education: Evidence from high school seniors, community college students, and adults. CEPA Working Paper No. 16-15. Stanford, CA: Stanford Center for Education Policy Analysis.

Burdman, P. (2005, October). The student debt dilemma: Debt aversion as a barrier to college access. (Discussion Paper)

Byrne, J. A. (2018, August 11). US students may collectively owe $\$ 2 \mathrm{~T}$ in loans by 2021. The New York Post. Retrieved from https://nypost.com/2018/08/11/usstudents-may-collectively-owe-2t-in-loans-by-2021/.

Camerer, C. F., \& Loewenstein, G. (2004). Behavioral economics: Past, present, future. In C. F. Camerer, G. Loewenstein, \& M. Rabin (Eds.) Advances in Behavioral Economics (pp. 3-52). New York: Russell Sage Foundation. 


\section{Higher Education Politics \& Economics}

Carlson, R. H., \& McChesney, C. S. (2015). Income sustainability through educational attainment. Journal of Education and Training Studies, 3(1), 108115.

Castleman, B. L., Baum, S., \& Schwartz, S. (2015). Behavioral economics and postsecondary access: A primer. In B. L. Castleman, S. Schwartz, \& S. Baum (Eds.) Decision making for student success: Behavioral insights to improve college access and persistence (pp. 1-20). New York: Routledge.

Combe, P. (2009, May 15). What the federal government owes student borrowers. Chronicle of Higher Education, 55(36). Retrieved from https://www.chronicle.com/article/What-the-Federal-Government/44352.

Cooper, J. (2007). Cognitive dissonance: 50 years of a classic theory. Los Angeles, SAGE Publications.

Cunningham, A. F., \& Santiago, D. A. (2008). Student aversion to borrowing: Who borrows and who doesn't. Washington D.C.: Institute for Higher Education Policy.

Dembecki, M. (2019, June 2), ED expected to nix gainful employment reg soon. Community College Daily. Retrieved from: http://www.ccdaily.com/2019/06/ed-expected-nix-gainful-employment-regsoon/.

DeSilver, D. (2018). U.S. students' academic achievement still lags that of their peers in many other countries. Washington, D.C.: Pew Research Center.

Dillman, D. A., Smythe, J. D., \& Christian, L. M. (2014). Internet, phone, mail, and mixed mode surveys: The tailored design method. Hoboken, NJ: John Wiley \& Sons, Inc.

Drezner, N. D., Pizmony-Levy, O, \& Pallas, A. (2018). Americans' views of higher education as a public and private good. New York, NY: Teachers College: Columbia University.

Durband, D. B., \& Britt, S. L. (2012). Student financial literacy: Campus-based program development. New York: Springer.

Experian (2018). Student loan debt reaches all-time high in 2018. Retrieved from https://www.experian.com/blogs/ask-experian/state-of-student-loan-debt/.

Farber, H. S. (2011). Job loss in the Great Recession: Historical perspective from the displaced workers survey, 1984-2010. Cambridge, MA: NBER.

Federal Student Aid. (2019). Public service loan forgiveness data. Retrieved from https://studentaid.ed.gov/sa/about/data-center/student/loan-forgiveness/pslfdata.

Federal Reserve Bank of New York. (2018). Quarterly report on household debt and credit, 2018: Q3. Retrieved from https://www.newyorkfed.org/medialibrary/interactives/householdcredit/data/pd f/hhdc_2018q3.pdf.

Fergus, D. (2018). Land of the fee: Hidden costs and the decline of the American middle class. New York, NY: Oxford University Press.

Festinger, L. (1957). A theory of cognitive dissonance. Stanford, CA: Stanford University Press. 
Fulwiler, S., Kelton, S., Ruetschlin, C., \& Steinbaum, M. (2018). The macroeconomic effects of student debt cancellation. Annandale-on-Hudson, NY: Levy Economics Institute.

Gbadamosi, A. (2009). Cognitive dissonance: The implicit explication in lowincome consumers' shopping behaviour for "low-involvement" grocery products. International Journal of Retail and Distribution Management, 37(12), 1077-1095.

Gladieux, L. E., King, J. E., \& Corrigan, M. E. (2005). The federal government and higher education. In P. G. Altbach, R. O. Berdahl, \& P. Gumport (Eds.), American higher education in the twenty-first century: Social, political, and economic challenges. (2nd ed.). Baltimore, MD: The Johns Hopkins University Press

Greenfield, J. S. (2015). Challenges and opportunities in the pursuit of college finance literacy. The High School Journal, 98(4), 316-336.

Hensley, B., Galilee-Belfer, M, \& Lee, J. J. (2013). What is the greater good? The discourse on public and private rules of higher education in the new economy. The Journal of Higher Education Policy and Management, 35(5), 553-567.

Higher Education Act 20 U.S.C. 1070-1099 (1965).

Hillman, N. W., Tandberg, D. A., \& Gross, J. P. K. (2014). Performance funding in higher education: Do financial incentives impact college completions? The Journal of Higher Education, 85(6).

Holtschneider, D. H. (2008, May). Colleges should teach students how to borrow wisely. Chronicle of Higher Education, 54(34). Retrieved from https://www.chronicle.com/article/Colleges-Should-Teach-Students/5140.

Iloh, C. (2018). Not non-traditional, the new normal: Adult learners and the role of student affairs in supporting older college students. Journal of Student Affairs, XXVII, 25-30.

Johnson, M. (2016). Raising the bar on efforts to increase financial capability among college students. In J. Liebowitz (ed.), Financial literacy education: Addressing student, business, and government needs (pp. 91-110). Boca Raton, FL: CRC Press.

Kelchen, R. (2018). Higher education accountability. Baltimore: Johns Hopkins University Press.

Kenney, D. (Producer), \& Ramis, H. (Director). (1980). Caddyshack [Motion picture]. United States: Orion Pictures.

Kraut, R., Olson, J., Banaji, M., Bruckman, A., Cohen, J., \& Couper, M. (2004). Psychological research online: Report of Board of Scientific Affairs Advisor Group on the conduct of research on the internet. American Psychologist, 59, 105-117.

Kuzma, A. T., Kuzma, J. R., \& Thiewes, H. F. (2010, April). An examination of business students' student loan debt and total debt. American Journal of Business Education, 3(4), 71-77.

Levine, A. (2001). Higher education as a mature industry. In P. G. Altbach, P. J. Gumport, \& D. B. Johnstone (Eds.), In defense of American higher education (pp. 38-58). Baltimore, MD: The Johns Hopkins University Press. 


\section{Higher Education Politics \& Economics}

Lobo, B. J., \& Burke-Smalley, L. A. (2018). An empirical investigation of the financial value of a college degree. Education Economics, 26(1), 78-92.

Manning, K. (2018). Organizational theory in higher education (2nd ed.). New York, NY: Routledge.

Miles, M. B., Huberman, A. M., \& Saldaña, J. (2020). Qualitative data analysis: A methods sourcebook. Thousand Oaks, CA: SAGE Publications, Inc.

Miller, J. J., \& Nikaj, S. (2018). Student loan debt, educational attainment, and tenure choice. Education Economics, 26(4), 393-410.

Mitchell, M., Leachman, M. Masterson, K, \& Waxman, S. (2018). Unkept promises: State cuts to higher education threaten access and equity. Washington, DC: Center on Budget and Policy Priorities.

Moody's Investors Service. (2011). U. S. private loan securitizations: 2012 outlook. New York, NY: Moody's.

Mueller, H. M., \& Yannelis, C. (2019). The rise in student loan defaults. Journal of Financial Economics, 131(1), 1-19.

Noble, H., \& Smith, J. (2015). Issues of validity and reliability in qualitative research. Evidence-Based Nursing, 18(2).

Nuckols, W. L. (2016). The perception of value added from accruing student debt to earn a degree or graduate certificate from a public institution of higher education: A descriptive study. Doctor of Philosophy (Ph.D.) Dissertation, Educ. Foundations \& Leadership, Old Dominion University. Retrieved from: https://digitalcommons.odu.edu/efl_etds/10.

Oliver, R. L. (1997). Satisfaction: A behavioral perspective on the consumer. New York, NY: McGraw-Hill.

Popesescu, G. H. (2017). Does student debt constitute a bubble that may bring about an educational crisis? Educational Philosophy and Theory, 50(2), 115118.

Privitera, G. J., \& Ahlgrim-Delzell, L. (2019). Research methods for education. Los Angeles, CA: Sage.

Robb, C. A. (2017). College student financial stress: Are the kids alright? Journal of Family and Economic Issues, 38(4), 514-527.

Sacerdote, B. (2017). Fifty years of growth in American consumption, income, and wages. Cambridge, MA: National Bureau of Economic Research.

Sawhill, I. V. (2018). Higher education and the opportunity gap. Washington, DC: The Brookings Institution.

Scott-Clayton, J. E. (2018). The looming student loan default crisis is worse than we thought. Washington, DC: Center on Children and Families at Brookings.

Sibson, K. B. (2014). Impact of the Post-9/11 G.I. Bill: An examination of retention of first year students in the Hampton Roads area. Doctor of Philosophy

(Ph.D). Dissertation. Educational Foundations \& Leadership, Old Dominion University. Retrieved from: https://digitalcommons.odu.edu/efl_etds/62.

Smith, C., \& Barboza, G. (2014, June). The role of trans-generational financial knowledge and self-reported financial literacy on borrowing practices and debt accumulation of college students. Journal of Personal Finance, 13(2), 28-50 
Snyder, T. D. (2012). Digest of educational statistics 2011. Washington DC: Institute for Education Statistics and the National Center for Educational Statistics.

Stoll, M. A. (2013). Great Recession spurts a shift to local moves. Providence, RI: US 2010 Project.

Tandberg, D. A., \& Hillman, N. A. (2014). State higher education performance funding: Data, outcomes, and policy implications. Journal of Education Finance, 39(3).

U. S. Federal Reserve. (2017). Report on the economic well-being of U.S. households in 2016 -May 2017. Retrieved from https://www.federalreserve.gov/publications/2017-economic-well-being-of-ushouseholds-in-2016-education-debt-loans.htm.

Wei, C. C. (2010). Trends in undergraduate Stafford Loan borrowing: 1989-90 to 2007-08. NCES 2010-183. Washington, DC: National Center for Educational Statistics, Institute of Education Sciences, U.S. Department of Education.

WILLIAM NUCKOLS, PhD, is the External Relations Manager in Distance Learning at Old Dominion University. His major research interests lie in the area of legal matters in higher education and distance learning. Email: wnuckols@odu.edu

KIM E. BULLINGTON, $\mathrm{PhD}$, is the Programs Manager and Chief Departmental Advisor in Engineering Management and Systems Engineering at Old Dominion University. Her major research interests lie in the area of veteran student success, underrepresented student success, and fraternity/sorority life. Email: ksibson@,odu.edu

DENNIS E. GREGORY, EdD, is an Associate Professor in the Higher Education and Community College Leadership Program at Old Dominion University. His major research interests lie in the area of higher education law and federal engagement in higher education. Email: dgregory@odu.edu 